\title{
The Life History of an Exemplary Provisional Republican: Gerry Adams and the Politics of Biography
}

\section{Stephen HOPKINS}

University of Leicester

\begin{abstract}
This article examines the biographical writing devoted to the critical individual in the history of the Provisional Irish republican movement, Gerry Adams. As President of Sinn Féin (SF) from 1983 until he stepped down in February 2018, Adams has been viewed by many as the key figure in the leadership of the Provisional movement, despite his long-standing and continuing denial of membership in the armed 'wing' of that movement, the Irish Republican Army (IRA). He has been interpreted as being instrumental in shaping, if not determining the evolution of Provisional republicanism, which began as a movement committed to violent insurrection in the cause of Irish unity and, after causing approximately $49 \%$ of the deaths during the 'Troubles', subsequently espoused a largely non-violent political strategy in the post-Belfast Agreement era after 1998. This article takes a comparative approach to the three biographies of Adams published to date, by Colm Keena (1990), David Sharrock and Mark Devenport (1997) and Malachi O'Doherty (2017). The argument pursued here is that the biographical study of political life-histories of emblematic individuals, such as Adams, may shed significant light upon the trajectory and character of the parties/movements which they lead. Moreover, the academic study of biographical writing should be an important resource for political scientists and contemporary historians, although there has been a tendency to marginalise this approach from the mainstream of the discipline of political science.
\end{abstract}

Keywords: Northern Ireland; Sinn Féin; Gerry Adams; biography; 


\section{Introduction}

At the SF ard fheis (annual conference) in 2017, after thirty-four years serving continuously as SF President, Gerry Adams TD announced that he had finally decided not to stand again for the leadership of the party. He argued that the timing of his departure had been collectively agreed, as part of a process of regeneration and renewal within the party. He was to have stood down alongside his long-time colleague in the leadership, Martin McGuinness, but the latter's illness and death in March 2017, had changed the nature of this plan. In an interview for SF's newspaper, he admitted that he would be 'relieved to be released from the formal responsibilities as leader but, like you [editor John Hedges] and every other republican, I have the responsibility to remain an activist [...]. I don't actually see it, apart from that, as a huge change in terms of my own personal life. Martin [McGuinness] said that Bogside republicans don't retire; neither do Ballymurphy republicans.' (An Phoblacht, November 2017, Special supplement, p.6). Nonetheless, the decision was widely held, both inside and outside the movement, to be a watershed in the history of Provisional republicanism.

In conventional political life history terms, it might be expected that Adams, having relinquished his leadership role, would devote himself to writing a memoir. However, he had already published two volumes of autobiography or memoir, the first of which, Before the Dawn (Adams, 1996) had appeared more than two decades earlier. This book dealt with Adams' early life, his internment and imprisonment during the 1970s, and his political evolution up until the republican hunger strikes of 1981. As was noted at the time, it was unusual for a senior figure in political leadership to write an autobiography whilst still in his or her forties, and whilst maintaining a position of power: 'political autobiographies should be written when the hurly-burly's done. They should tell a story whose ending is known, reflect on something that has actually been achieved.' (O'Toole, 1996). Notwithstanding this advice, Adams wrote a second volume of memoir, Hope and History (Adams, 2003), which concentrated upon the 'peace process' of the 1990s, culminating in the difficulties associated with implementing the Good Friday/Belfast Agreement of 1998. On publication of this second volume, Adams recognised that his narrative remained incomplete; he was cited saying that 'there is a natural third book [...] but apart from noting that in my head, I have no plans, notions, ambitions to even think about writing it at the moment.' (Belfast Telegraph, 29 September 2003). So, it may well be that, as he takes something of a back-seat in terms of his formal political role, Adams may yet fulfil this gap in the self-construction of his life- 
history. However, readers of Gerry Adams' oeuvre have yet to be furnished with a 'real and fully truthful autobiography.' (O’Toole, 1996). In a similar vein, Roy Foster has cautioned readers of Irish autobiography to be aware of a 'recurring theme' in such writing: 'the deliberate gap in the narrative: the momentous elision, the leap in the story.' (Foster, 2001: 3). Perhaps surprisingly, Adams (1996: 2) himself has acknowledged that his own memoirwriting has been characterised by these gaps:

I am also conscious that the elements of conflict remain today and retain their potency. For this reason I must write nothing which would place in jeopardy the liberties or lives of others, so I am necessarily constrained. It is probably an invariable rule that the participants in any conflict cannot tell the entire story until some time after that conflict is fully resolved.

More than twenty years since writing these words, and despite the decision of the Provisional movement to bring a formal end to its violent campaign in 2005, it is doubtful whether Adams would agree that the conflict has been 'fully resolved'. Indeed, for Adams the teleological destination of the 'peace process' remains the ending of partition and the creation of a united Ireland. The unspoken implication is that only in such circumstances would it be feasible to 'tell the entire story' and produce an authentic, truthful account of his part in the 'struggle'.

Equally, biographers might be expected to use the historical moment of Adams' relinquishing of the SF Presidency as an opportunity to work on a rounded, retrospective portrait of their subject. However, this conventional understanding is complicated by a number of factors: first, it remains unclear to what extent Adams intends to withdraw from his public and political roles (as well as his Presidential role in SF, Adams has been a TD in Co. Louth since 2011, and he has announced that he will not stand again for the Dáil); it has been speculated, for example, that he might be interested in contesting the Irish Presidential election, which is due to be held in late 2018. Adams himself has only stated that he will 'support the new Uachtarán [President] and the Sinn Féin leadership and I will be available to do whatever they want me to do. [...] I don't want or expect to have more influence than you or any other member of the party. (An Phoblacht, November 2017 Special supplement, p.7). 
Allied to his memoirs, Adams has written prolifically, authoring a range of material, including a local history of the Falls district in West Belfast (Adams, 1982), a historical essay on Belfast and the 1916 Easter Rising (Adams, 1991), short stories and autobiographical fiction (Adams, 1990, 1992), collections of political writing and journalism (Adams, 1986, $1994,1997,2001,2005,2007)$ and a book of 'tweets' from his forays into social media (Adams, 2016). His most recent collection of short articles, Never Give Up (2017) dealt with an eclectic range of subject material, including biographical sketches of departed 'friends and comrades' such as McGuinness, the Redemptorist priest Fr. Alec Reid (who helped to broker talks between Adams and the leader of 'constitutional nationalism' in the North, John Hume), Nelson Mandela, Fidel Castro and SF leader Máire Drumm. It is hard to resist the conclusion that Adams, at almost 70 years old, has begun to contemplate his own mortality; the death of his close friend McGuinness has clearly hit him hard ('I was up in Donegal the other weekend for a couple of days and I couldn't get him [McGuinness] out of my head. I miss him very, very much - personally as well as politically.' [An Phoblacht, November 2017, Special supplement, p.6]).

In many ways, of course, Adams has spent almost his entire political life in close proximity to violent death, whether walking behind or carrying the coffins of many of the nearly 300 IRA volunteers killed during the conflict, or attempting to justify the IRA's 'armed struggle', and its litany of killings. ${ }^{1}$ Yet, Adams has been a survivor, both in literal or physical terms, after he was shot and injured during a loyalist assassination attempt in 1984, but also politically. His political demise was confidently predicted on several occasions during the course of his Presidency, particularly in more recent years as other leaders of the 1960s 'Troubles' generation have, willingly or unwillingly, left the political stage. ${ }^{2}$ In 2008 and into 2009, in the wake of disappointing election results to the Dáil, and then in local elections and the European parliament election, there was widespread speculation regarding Adams' position; Liam Clarke argued that he was SF's 'worst asset' (Sunday Times, 7 June 2009), partly because he 'can't resist embroidering a story. Much of what he says is for effect; he doesn't stick to the literal truth [...] Adams and other veterans of the IRA years are obstacles to coalition [in the Republic]. They have too much to cover up; no other party with any sense can risk touching them with a bargepole. Despite their past services to Sinn Féin, they have become a drag on its progress.' Anthony McIntyre (an ex-Provisional, but an implacable critic of Adams since the mid-1990s), commenting on criticism of Adams in the usually compliant Andersonstown News, remarked that he now stands 'increasingly isolated 
as the sole remaining dinosaur of Northern Irish politics $[\ldots]$ an antediluvian figure from the 1980s.' (McIntyre, 2008). Despite this journalistic assault, there was no appetite within SF for a challenge to Adams' leadership, and the improved performance of the party in the 2011 parliamentary election in the Republic arguably helped to cement his control. ${ }^{3}$

The article's first section briefly analyses the advantages and pitfalls of utilising a life-history or biographical approach to the study of political movements, and provides a defence of the use of such personal narratives in the discipline of politics. The article then considers the three published biographies of Gerry Adams to date, in terms of the ways in which they examine a number of key issues or questions in Adams' life-history. For example, how they interpret Adams' coming of age as a member of the republican movement; specifically, the article analyses the significance attached to familial and ideological dimensions of this issue. Following this discussion, the article will examine the ways in which Gerry Adams' denial of membership of the IRA has been interrogated. In these substantive sections the article considers the use that his biographers have made of Adams' own writing. Although Adams has not collaborated with any of his biographers thus far, his writings have supplied ample material from which to reconstruct the life-history of this complex and elusive figure.

\section{Biographical Writing and Political Life-History}

In the humanities and social sciences, there has been an increased interest over recent decades in the complexity of individual or personal narrative analysis. It has been argued that 'human agency and individual social action is best understood in connection with the construction of selfhood in and through historically specific social relationships and institutions.' (Maynes, Pierce and Laslett, 2008: 2). In this analysis of the stories that are told about individual lives, researchers need to be mindful that these stories are "very much embedded in social relationships and structures and that they are expressed in culturally specific forms; read carefully, they provide unique insights into the connections between individual life trajectories and collective forces and institutions beyond the individual.' (Ibid: 3 ). If this applies most clearly for autobiographical sources, it can also be seen as relating to biographical studies. The study of biographical writing generally involves an effort, on the part of both the author and the researcher, to grapple with the complexities of the subject's relationship to the social and political context in which the life is lived. In historical 
scholarship there has been important work which has utilised a prosopographical approach, which has based itself on a breadth of oral, literary and documentary sources (e.g. Morgan, Flinn and Cohen, 2004). For social scientists, there is an understandable scepticism with regard to the subjective or unverifiable elements of life-writing, but a careful reading of such sources can permit a more nuanced and detailed understanding of social actors and causation. The approach taken here is that the study of biographical writing does not require the researcher to limit herself to the scope of a single individual and his or her story. No individual life is lived entirely under one spotlight; rather than producing a record of individuality, the study of life-writing can highlight instead the complex web of interconnections between the subject and the world, whether at the familial level, or at a broader communal or even national and international level (Hopkins, 2013).

In an influential discussion of the British approach to political life history, Rhodes (2012) has argued that there has been a tradition of 'tombstone biography', concerned with describing more than analysing the lives of the 'great and the good'. There was little attention in such biographical writing to the need to place the life in any complex institutional or structural context, and such writing erred towards the hagiographical. In keeping with this limited perspective, there was often a failure to consider or explore the links between the private self and the public face of political action. In short, this was a tradition that generally shied away from theorising about life history, where the implicit belief was that attention to factual detail, often based upon exhaustive mining of the documentary archives, was what really counted in biographical research. In many ways, such traditional understandings have been significantly complicated by the 'interpretive turn' in social sciences, which has recognised that life histories can be preoccupied with a subject's identity, motivations or character, and that disciplinary boundaries are necessarily porous or blurred. For Rhodes (2012: 171), it is necessary to break the shackles of a British tradition of political life history, one that has been characterised by a strictly chronological approach and which has privileged the public over the private, as well as description over analysis and interpretation. Arguably, as the highly centralised, hierarchical Westminster model of government has been subject to change and decline in recent decades, so political life history should reflect this evolution. Contemporary political biography, in this context, may be expected to address issues beyond the narrow public life itself.

Of course, the Irish republican movement, and perhaps the nationalist movement more broadly, has not conformed to the Westminster model sketched above, nor has it 
produced a body of conventional 'Ministerial' life-writing of the type that is common among British politicians. Nonetheless, it has been both highly centralised and hierarchical; the IRA and SF have been part of a self-declared revolutionary movement, characterised by a clandestine and militaristic internal organisation and political culture (English, 2003; Alonso, 2007; Smith, 1995). There has been a long-standing focus upon the figure of the iconic leader, both during and after the revolutionary era of 1916-1923, when personal narratives or biographies associated with legendary republicans, such as Michael Collins (O'Connor, 1991), Eamonn De Valera (Fanning, 2015) and Constance Markievicz (O’Faoláin, 1934; Arrington, $2016^{4}$ ) have created what has been described (in the different, but related, context of the historiography of the international communist movement) as a 'personalised form of official party history.' (Morgan, 2005: 56). It is interesting to note that both O'Connor and O'Faoláin had been volunteers in the republican movement, so both knew intimately this culture, one which their biographical subjects shared. However, both had come to a critical understanding of that culture, which acknowledged the limitations of republican ideology. In the more recent era, there have been biographical studies of SF and/or IRA leaders such as Martin McGuinness (Clarke and Johnston, 2001) and Ruairi O’Bradaigh (White, 2006). However, Gerry Adams stands as a uniquely emblematic figure in Provisional republicanism, one who has dominated the movement's trajectory, as well as the narrative construction of its historical evolution. For avowedly collectivist and revolutionary movements, this biographical dimension of political analysis may be "subtly disintegrative of more structured causation.' (Morgan, 2001: 10).

\section{Ballymurphy and the Ties that Bind}

Although it might be an exaggeration to argue that Gerry Adams was, throughout his tenure as President, the 'undisputed leader' of the Provisional republican movement (Maillot, 2005: 98), he certainly proved to be highly adept at remaining at the apex of what was a notoriously fractious organisation(s). Whilst at various junctures, he was surrounded by a small, largely self-perpetuating, coterie of loyal supporters, mainly drawn from among the ranks of Belfast republicans such as Danny Morrison, Tom Hartley and Ted Howell (often described as a 'kitchen cabinet' or 'think-tank'), it is Adams himself who has enjoyed (or endured, if we are to believe his protestations) national and international celebrity. However, his biographers are in agreement that one of the key features in understanding Adams' life-story, and one of 
the reasons for his longevity, is his rootedness in the deeply republican milieu of West Belfast, and perhaps even more specifically Ballymurphy, where the family moved into a newly-built house at Divismore Park when he was only a toddler. Adams was also partly brought up by his paternal grandmother in the Lower Falls, where he attended St Finian's De La Salle primary school, and subsequently St Mary’s grammar school. An analysis of Adams' own writing about the local history of both these strongly republican districts underlines the extent to which there are 'intimate imbrications of politics with streetscapes in Catholic West Belfast.' (Zwicker, 2001-2: 91).

Both Sharrock and Devenport, and O'Doherty, begin their biographies by situating Gerry Adams within a familial and geographical setting that was deeply marked by the long history of Belfast republicanism, stretching back into the nineteenth century, and even further to the Belfast influence on the United Irish rebellion of 1798. In the case of Sharrock and Devenport (1997: 5-21), they open their book with a reconstruction of the shoot-out in 1942, in which Gerry Adams senior, then sixteen, was injured, and in which an RUC officer was killed. On both sides of his family, Adams' republican pedigree was unimpeachable: 'the Adamses and the Hannaways had emerald green blood running through their veins.' (Ibid: 27). His biographers present his initiation into republican politics as almost a matter of destiny or osmosis, rather than a considered ideological choice. In his introduction, O'Doherty (2017: 1-5), rather than concentrate upon his father, chooses to focus upon Adams' mother, Annie, who had seen all of her five surviving sons imprisoned for republican activity at various stages. O'Doherty cites Gerry's younger brother, Dominic, who in his own prison memoir stated: 'My mother had been a republican all her life and had never once attempted to dissuade her children from being the same.' (Adams, D., 2016: 4). In Keena's biography (1990: 9-22), the introduction focuses upon Adams' arrest and internment in March 1972, followed by his release to attend the talks between the IRA and the British government in June that year. Adams' republican inheritance and his formative years are touched on only briefly, and without very much detail. In may be speculated that, without Adams' own memoir to draw on, Keena found it relatively difficult to find reliable sources for his early life and influences.

What is significant to note here is that Adams was not one of those many hundreds of Belfast Catholics who joined the republican movement on foot of the breakdown of law and order, and sectarian rioting during the summer of 1969. His route into political commitment had been mapped out at an earlier stage. All his biographers state that he joined SF, and $\mathrm{Na}$ 
Fianna Éireann in 1964, and Sharrock and Devenport (1997: 35) add unequivocally that he joined the IRA in 1965, aged sixteen. They are not convinced, and neither is O'Doherty, by Adams' own declaration (1996: 51-2) that 'despite my firmly republican family background, I had not really formed any definite political views' up to the point at which there had been rioting on the Falls Road, when the RUC removed an Irish tricolour from the election office of Liam (Billy) McMillen, the SF candidate, in 1964. It seems uncontroversial that Adams had both absorbed a republican culture in the bosom of his family, and therefore that his decision to join the movement was not an act of teenage rebellion. There was no conversion to the 'good old cause', no epiphany or awakening; instead, he was effectively confirmed in a familial belief system. If activists could be ranked along a 'continuum of graded purity', as Halfin argued (2003: 27) in the different, but related, context of communist revolutionaries, then Adams could expect to be welcomed and have his republican bona fides accepted, given that he hailed from a 'historic' family known for its fidelity and sacrifices for the cause. Adams has always maintained this fidelity, both to his immediate family, but also to the republican 'family' in Ballymurphy (specifically D Company of the IRA's $1^{\text {st }}$ Battalion of the Belfast brigade). Adams (1996: 18) himself has described Ballymurphy in terms of its generic characteristics as an ordinary working-class community: 'In my travels over the years I have seen Ballymurphys everywhere. In Britain, across Europe, in cities throughout Ireland, in the USA and in South Africa.'

Keena argued that the increasing alienation of the Catholic districts from the British Army in 1970-71 represented 'an example of an entire community involved in a structured revolt'. For Adams, this period, and the effort to build an alternative state in enclaves such as Ballymurphy, represented 'one of the high points of his life.' (Keena, 1990: 44; de Baroid, 1989) Sharrock and Devenport (1997: 443) cite Fr Des Wilson (the priest who married Adams and Colette McArdle), who argued that despite making alliances all over the world on behalf of Irish republicanism, this did not separate Adams 'from the people he came from. I think one of the reasons for that may well be that he comes from a family which has very deep local roots and very deep political republican roots [...]'. Others have characterised this sense of 'rootedness' as part of a more calculated political strategy (Hopkins, 2009). Foster (2002: 176) pointed out that Adams' 'most passionate commitment is to the narrow world of West Belfast, a self-justifying and tightly-knit community later replicated in the republican wing of internment prison.' In Adams' own writing, his personal story is always subsumed into the heroic collective 'resistance' of the Ballymurphy community, and this interpretation 
is a strategic attempt to present himself as a 'man of the people', grounded in the concerns and common sense of his community. Adams is 'determined to see things purely in the perspective framed by his mother's back window.' (Ibid: 177). O’Doherty (2017: 65), looking back from a vantage point which allows him to utilise Adams' own self-presentation over forty years, reinforces this more critical perspective: 'Adams' evolving political method was to assert that the community had a coherent voice and that he understood it better than his critics did.' In more recent times, and certainly since the Good Friday Agreement in 1998, Adams has, as part of a determined SF campaign, gone further and sought to identify the Provisional movement, both in contemporary and historical terms, as if it was the true representative of the whole of the Catholic nationalist community, and not simply its republican sub-section. (Todd, 1990?; Hopkins, 2013) This attempt to wrest control of the historical narrative of the conflict has been seen recently in the fiftieth anniversary of the Northern Ireland Civil Rights Association, and the controversy generated by SF's efforts to 'colonise' the communal memories of this non-violent campaign. ${ }^{6}$

\section{Gerry Adams, Civil Rights and Political Violence}

The biographers of Adams have struggled to provide an in-depth portrait of his contemporaneous attitude to the evolution of the non-violent campaign for civil rights and socio-economic reform in Northern Ireland during the late 1960s. By extension, they have also found it difficult to assess Adams' nuanced position in the split within the republican movement, which led to the formation of the Provisionals (and the 'Officials') in the same period. There is a consensus that Adams was, initially at least, enthusiastic about the increasing emphasis upon political campaigning (particularly around housing provision) that was promoted by the Dublin leadership of the IRA (under Cathal Goulding), and his early local mentor, Billy McMillen (Keena, 1990: 30-1; Sharrock and Devenport, 1997: 44). However, there is much less clarity regarding Adams' understanding of the civil rights agitation, and the extent to which he genuinely accepted the left-wing direction of the Goulding leadership. Adams did not attend the key civil rights march in Derry in October 1968, as he was working a shift as a barman at the Duke of York; he did claim to have been at the start of the People's Democracy march in Belfast on New Year's Day, 1969, but Sharrock and Devenport (1997: 52) report that, of the small band who were present, "nobody seems able to remember the young barman's presence.' O’Doherty (2017: 29-30) portrays 
this period in terms of Adams' friendship with another charismatic young republican, Joe McCann, who would side with the Official IRA after the split, and who became an iconic figure after he was killed in a shootout with the British Army in 1972 (Ibid: 71; Mulqueen and Smyth, 2010). O'Doherty, who hails from a West Belfast nationalist background, argues that neither Adams nor McCann were rebels in a late 1960s counter-cultural or generational sense; both remained practising Catholics at this time, and they were not especially inspired by the student protests of Paris or the anti-Vietnam war movement.

In these portrayals, Adams can be discerned as a questioning and rather quiet young man, someone who was not obviously opposed to the left-wing rhetoric espoused by the republican movement's leadership. But, ultimately, in the maelstrom of sectarian confrontation, which exacerbated the tension in Belfast during 1969, and culminated in the rioting of August, Adams came to an understanding that non-violent reform of the political system in Northern Ireland was simply not a realistic prospect. Sharrock and Devenport (1997: 49) suggest that 'a combination of his family's background of violent republicanism and a pinch of scepticism drawn from what he saw on the ground [in Ballymurphy] may have made Adams wary of fully embracing the Goulding approach.' English (2003: 110) has a similar perspective: 'A republican family embedded in Ballymurphy's Catholic community helped engender in Gerry Adams a republican sensibility from early on; the immediacy of northern needs was interwoven with the longevity of republican attachment.' Keena (1990: 33) argued that Adams 'felt the republican leadership were unable to give proper direction', and he began to argue with McMillen. This discussion of the young Adams' relationship to the civil rights movement, and the direction being pursued by the republican leadership at the time, is a good illustration of the way in which the study of an individual's political trajectory can shed light on the broader questions pertaining to the movement. In this case, the Provisionals' contemporary claim to being the true inheritors of the struggle for civil rights is clearly undermined by a close reading of Adams' biography, and his ambivalence with regard to reformist or gradualist efforts to create a non-sectarian politics in Northern Ireland.

In similar vein, there is some interesting debate concerning Adams' decision-making in the lead-up to the split in the republican movement in late 1969. Both Keena and Sharrock and Devenport point to a growing ideological divergence in the Belfast IRA, but there is some uncertainty regarding the position of the twenty year-old Adams. A pragmatic reason has been advanced for his eventual decision to side with the Provisionals; namely, he was facing disciplinary action for his involvement in moving arms against the orders of the 
Belfast leadership. During this activity, another young republican Liam McParland was killed in a car crash, and Adams was suspended from his role in the movement (Sharrock and Devenport, 1997: 64-5; Keena, 1990:40-1; O’Doherty, 2017: 44-5). Of course, the fact that he was engaged in moving weapons and training new volunteers, in preparation for renewed sectarian confrontation and the defence of the Catholics of West Belfast, suggests that Adams had already adopted a position that was at odds with the Dublin leadership's desire to deescalate the crisis.

However, it still 'caused some surprise' when it became known that 'he was siding with the traditional, militant element' (Keena, 1990: 41). Adams ended up aligning himself with older, more traditional republicans, many of whom had dropped out of activity in protest at the leftist direction of the 1960s. O'Doherty (2017: 48) speculates that the 'deciding factor' in Adams' decision may have been family ties, rather than ideology: 'the Hannaways and Gerry's father had sided with the defectors.' The only member of the family who remained with the Officials was his older sister, Margaret. It might be more accurate to argue that the republican movement's ideology has always been marked strongly by familial and communal ties, and these bonds have usually been more important for individuals than the specifics of political, social or economic policy espoused by the movement in any given era.

\section{On (not) being an IRA Volunteer}

Maynes, Pierce and Laslett (2008: 3) make the important point that 'in analyses of life histories, two salient temporalities continually interact. Historical time contextualizes a life course, even while the narrator's moment in the life course affects how he or she experiences, remembers and interprets historical events.' We can add that in biographical writing, it also matters at what historical juncture the biography is produced, and the perspective from which the biographer is writing. As has been noted, Gerry Adams has continued to deny that he was ever a member of the IRA (prior to the 1969 split), or of the Provisional incarnation of the 'Army'. Yet, this denial has meant different things at different times, and his biographers have interpreted the motivation behind this implausible claim in diverse ways.

It is worth briefly rehearsing the weight of scholarship which has refuted Adams' denial of membership. There is virtual unanimity amongst both biographers and researchers that Adams joined the IRA in the mid-1960s, was 'officer commanding' (OC) of the $2^{\text {nd }}$ 
Battalion of the Provisional IRA in Belfast from 'April/May 1971 and March 1972 [...]; in the latter year he became Adjutant for the Belfast Brigade as a whole; by the time of his arrest on 19 July 1973 he had become OC of the entire Belfast Brigade.' (English, 2003: 110). After his release from Long Kesh in 1977, it is alleged that he joined the IRA's Army Council, 'a position which he was to hold for a long time.' (Ibid: 110). It is argued that Adams was not held in high regard as an 'operator' in the IRA; 'his main contribution was strategic thinking but this didn't impress the men who had killed and laid bombs.' (O'Doherty, 2017: 100). He was not generally engaged in day-to-day IRA activity from the early 1980s onwards, but nevertheless retained a key leadership role (Sharrock and Devenport, 1997: 197-8). The biographers contemplate the reasons for Adams' insistence that he was never in the organisation, against a welter of evidence from erstwhile members and other analysts. ${ }^{7}$ Of course, the potential for self-incrimination and criminal charges are one facet of this reluctance to acknowledge his past. Adams was charged with IRA membership after the horrific La Mon bombing in 1978, but the judge ruled that there was insufficient evidence to proceed to trial (Keena, 1990: 84; Sharrock and Devenport, 1997: 157-61; O’Doherty, 2017: 132-8). The republican campaign surrounding the case arguably aided Adams in raising his profile within the movement, and he was, soon after his release, elected as vice-President of SF.

Although Keena makes no secret of his conviction that Adams was a senior IRA figure, the latter's denials were not such a public issue at the time of publication of this biography in 1990. The context is critical, as always. After all, the IRA campaign of violence was still ongoing, and Adams was engaged in a dialogue with John Hume concerning how it might be possible to bring the IRA to a ceasefire, and thereby end the (self-imposed) isolation of the republican movement. It made pragmatic sense to turn a blind eye to Adams' IRA leadership role in the context of encouraging the 'peace faction' in the Provisionals, and of maintaining his position of dominance, which would be required to bring the bulk of the movement to a compromise which involved the implicit renunciation of many of the movement's articles of faith. Arguably, in 1996-97, when Sharrock and Devenport were working on their biography, a similar logic prevailed in government circles, and Adams' 'incredible assertions', repeated in Before the Dawn, were allowed to pass with 'no more than mild expressions of scepticism.' (O’Toole, 1996).

One of the reasons that republicans reacted in such a hostile fashion to Sharrock and Devenport's biography (Bennett, 1998) was that it undermined the fiction that the IRA and 
SF were actually separate organisations, and they argued persuasively that Adams was the effective leader of a (largely) unified movement. Devenport, in his own memoir (2000: 201) pointed out that he and Sharrock's biography was obviously seen as a 'counterblast' to Adams' memoir, and that SF 'was not best pleased'. At the time the biography appeared, the IRA had only recently reinstated its ceasefire, which had ended in February 1996 with the bomb at Canary Wharf in London. Gerry Adams had been arguing in his memoir that SF was an entirely separate organisation, which deserved to be in all-party talks on the basis of its electoral mandate alone. A second reason for SF hostility was that Devenport was English, and the BBC's Ireland correspondent, whilst Sharrock (also English) was the Guardian correspondent in Belfast; as such, they were viewed as writing primarily for a British (or English) audience, and exposing the SF President as an exponent of the 'art of political lying' (Aughey, 2002) was bound to bring a hostile response. Devenport left Northern Ireland for a posting in the Middle East not long after the biography appeared.

In a somewhat paradoxical fashion, O’Doherty's biography can be seen as more preoccupied with the IRA past of the SF President, despite the definitive ending of the Provisionals' 'armed struggle' in 2005. Almost thirty years after Keena's relatively low-key treatment of Adams' IRA affiliation, and after nearly thirty years of continued denials by Adams, O’Doherty used his biography to undertake a more intensive scrutiny of this past. Increasingly in Northern Ireland, questions turning on the legacies of the conflict, and the shaping of the historical narrative of the 'Troubles' have been inescapable in contemporary political life. As O'Toole (2003: 14) put it: 'the danger has always been that the tacit agreement to ignore the IRA past of the SF leader would encourage a larger and more profound act of denial. If Adams did not have to account for his involvement with the IRA, then perhaps the IRA itself could remain unaccountable.' O'Doherty (2017: 209) reported that as far back as 1987, a former IRA prisoner Gerard Hodgins, then working as a SF press officer, had written a briefing for Adams, in which he argued that it would be better for the SF President to acknowledge his membership, 'put it out of the way, put it to bed and it'll not come back to bite you again.' The advice was declined.

O'Doherty (Ibid: 221) proceeds to demonstrate the fashion in which Adams has attempted to circumvent the narrow question of membership, and by extension the wider issue of historical accountability: in the 'post-conflict' era, the IRA's violence was 'to be presented as a by-product of bad politics and not as something for which he would accept responsibility or even for which he would accept that the IRA itself should be called to 
account.' Adams has often argued during the last two decades that he does not seek to 'dodge his responsibilities' for what occurred in the past, but O'Doherty underlines that he never unambiguously spells out what those responsibilities really are. The 'rhetorical device' that Adams has used over and over again is that he does not renounce the 'struggle' of the IRA; indeed it was, in the words of the 2005 statement ending the campaign of violence, 'entirely legitimate'. However, Adams has said that he doesn't 'for one second' step back from his responsibilities as 'leader of a struggle that has caused both hurt and damage to other human beings. I don't walk away from that.' (Ibid: 258). The implication in Adams' own writing over the past two decades is that others (not least the British government) have not been as willing to recognise their true role in the conflict. ${ }^{8}$ Yet, his consistent refusal to be even minimally honest regarding his own past has certainly made it more difficult for Adams to credibly promote this message to a broader audience in Northern Ireland and beyond.

\section{Conclusion}

Both O'Doherty and Sharrock and Devenport sub-title their biographies as 'unauthorised', or at least their respective publishers made that decision. The clear implication is that an 'authorised' biography would not be truthful. The question of the intended audience for these works, and the political vantage point of the biographers, is also of interest: Keena, a journalist based in Dublin at the time of writing his biography, used a publishing house based in Cork and Dublin, and in his historical assumptions and some of his views regarding the conflict in Northern Ireland, he could be characterised as writing primarily with an Irish audience in mind; one which would interpret Gerry Adams' life story within the prism, broadly conceived, of Irish nationalist precepts. Keena (1990: 23) was clearly sympathetic to the Catholic nationalist population's plight in post-partition Northern Ireland: 'for the entire Catholic population of the six counties, but especially for the outnumbered residents in West Belfast who lived so close to similar Protestant areas, fear lay at the bottom of their political relationship with the state.' Sharrock and Devenport's book came out with a much larger, London-based publisher, and as 'blow-ins' (Devenport, 2000: 4-14) or outsiders in Northern Ireland, they implicitly understood their remit as interpreting Gerry Adams' life story for a British, or perhaps international, audience.

Malachi O'Doherty approached the writing of his biography of Adams as someone with a Catholic nationalist/republican upbringing in Riverdale in West Belfast. Furthermore, 
O'Doherty, born in 1951, was from the same political generation as Adams. He was clearly, in some important senses, an 'insider', who knew intimately both the community and the socio-political context within which Adams' life-story had played out. He understood, indeed had been brought up in, the culture and educational system that had produced the republican movement, but nonetheless O'Doherty had rejected this political choice. In two previous works analysing republican strategy (O'Doherty, 1998) and the tumultuous year of 1972 in Belfast (O’Doherty, 2007) he had effectively included elements of autobiographical reflection in his writing. O'Doherty's own father had been a republican, and one 'who probably never felt the need to take seriously anyone who disputed' the main tenets of the republican creed (2007: 9). In choosing journalism as a career path, O’Doherty was explicitly rejecting participation in the 'struggle' and violence that was being unleashed all around him in the early 1970 s.

In his introduction to his critique of the Provisional movement (1998: 10-33), he compares his trajectory with that of his near-contemporary, Gerry Adams. O'Doherty (Ibid: 10) stated that the purpose of this book overall was to 'pick off' some of the 'myths' perpetuated by the Provisionals: 'the myth of the IRA as a defence force for Catholics; the myth the IRA is a guerrilla army engaged in war; the myth that they are the voice of a community [...]'. His rationale for including the autobiographical chapter is illuminating: 'If you know my baggage, and the inclination of my prejudices, then you can take them into consideration when weighing up my ideas. I won't pretend to have no such prejudices, but I will make an honest effort to disclose them.' (Ibid: 11). This provides an interesting contrast with Adams' own comment, at the start of Hope and History: 'It is not my business to offer an objective account of events or to see through someone else's eyes. Nor is it my responsibility to document these events. My intention is to tell a story. It is my story. My truth. My reality.' (2003: 2). In a radio phone-in programme after his biography was published, O'Doherty revealed something of the discussion he had had with his editor at Faber, regarding the tone of the book: 'Look [said the editor], this book-there's two ways this book could go. You can write a j'accuse - I attack Gerry Adams - here it is - here's the goods, throw it at him and hammer it, you know? Or you can stand back from it. [...] you can be more measured. You can allow room for the other point of view. You can show some respect for the man and allow for the fact that people who have regard for him and do respect him and do follow him might read your book as well.' O'Doherty said that he had chosen the second approach. ${ }^{9}$ 
O'Doherty, in his biographical endeavour, therefore has two significant advantages over Keena and Sharrock and Devenport. He has a great deal more material with which to work; he can write, using Adams' own voluminous publications, as well as being able to reconstruct a life-story which is closer to its end-point than twenty or thirty years previously. Moreover, he is also more familiar with the communal context for Adams' life-story than his previous biographers. He uses these relative advantages in an effort to construct a psychological portrait of Adams, and the second half of the biography, in particular, details a number of highly contentious and difficult personal and political events that Adams has had to grapple with since the end of the IRA's campaign. These include his arrest and questioning in 2014 with regard to the 1972 murder and 'disappearance' of mother of ten, Jean McConville (O'Doherty, 2017: 285-91), as well as the revelations concerning child sexual abuse within Adams' own family, involving both his father and brother (Ibid: 239-40; 26775). However successful O'Doherty has been in this project, and the reviews were by no means united in this regard ${ }^{10}$, there is certainly an effort to combine an interpretation of the individual life-story, focused upon Gerry Adams' personal character and motivations, with the contextual history of the Provisional republican movement. The emphasis in both Keena and Sharrock and Devenport is arguably more concerned with the latter dimension than the former. However we 'read' these biographies, though, the argument here is that they provide researchers with critical sources for furthering our understanding not simply of Adams' own career, but also the ways in which the Provisional republican movement's role and historical narrative of the violent conflict may be interpreted.

\footnotetext{
${ }^{1}$ The Provisional republican movement produced a commemorative publication (Tírghrá - Ireland's Patriot Dead, 2002) that listed 364 republicans who were killed during the 'Troubles' (volunteers of the IRA, members of SF, as well as those who belonged to affiliated organisations such as the women of Cumman Na mBan, and the youth of Fianna Éreann).

2 John Hume of the Social Democratic and Labour Party led his party from 1979 until his retirement in 2001. Ian Paisley led the Democratic Unionist Party from its foundation in 1971 until he stood down in 2008. With Paisley's retirement, Adams was unmatched in terms of the longevity of his leadership in Northern Ireland, apart from his friend, Martin McGuinness.

${ }^{3}$ For further evidence of the critique of Adams' leadership in this period, see Mick Fealty, 'It's time for Gerry Adams to go', Guardian, 23 July 2009; Conor McMorrow, 'Is Sinn Féin still Adams’s family?', Sunday Tribune, 10 August 2008; Malachi O’Doherty, 'Could Gerry Adams be living on borrowed time?', Belfast Telegraph, 16 May 2008.

${ }^{4}$ Arrington's approach is particularly insightful, and illustrates some of the main elements in contemporary biographical writing. It is also a 'double biography', undertaking to analyse the intertwined lives of both Constance and Casimir Markievicz.

${ }^{5}$ For details of this 'small group of trusted confidants and advisors', see Moloney (2007: 401).
} 


\begin{abstract}
${ }^{6}$ For details of this controversy during the fiftieth anniversary of the civil rights movement, see SF National chairperson Declan Kearney's article, 'We have come Full Circle: Northern Nationalism has Politically Remobilised' (http://eamonnmallie.com; January 29, 2018). And for responses, see former SDLP leading figure, Bríd Rodgers, 'Is Sinn Fein so ashamed of its own past that it has to rewrite it?' (http://eamonnmallie.com; February 1, 2018). The veteran civil rights activist from Derry, Eamonn McCann, made the comment that SF was seeking to 'colonise' the history of the movement (Irish News, February 2, 2018).
\end{abstract}

7 Among many others, see the testimony by Adams' erstwhile close comrade, Brendan Hughes, in Moloney (2010: 76-7; 106-7).

\footnotetext{
${ }^{8}$ For example, Adams led a 'March for Truth', organised by SF, in West Belfast in 2007. In his speech, he called for full disclosure of the British state's role in 'violence and collusion' with loyalist paramilitary 'death squads'. It was surely predictable that Adams was condemned in many quarters for the apparent hypocrisy of his call for full disclosure. (Hopkins, 2013: 37).

${ }^{9}$ Interview with Malachi O’Doherty by William Crawley, BBC Radio Ulster, 4 September 2017. The transcript is available at http://thepensivequill.am/2017/09/inconvenience-of-conviction.html

${ }^{10}$ Perhaps unsurprisingly, there was a hostile two-page review of O'Doherty's biography in An Phoblacht (October 2017, 12-13). The reviewer argued that 'the terminology used in the book is largely pejorative to the point of Establishment, anti-republican propaganda. [...] Reading this book is a waste of time. [...] it offers nothing new except an insight into the mind of Malachi O'Doherty. And that is not a good place to visit.'
}

\title{
References
}

Adams, D. (2016) Faoí Ghlas (Belfast: Dominic Adams)

Adams, G. (1982) Falls Memories (Dingle: Brandon).

Adams, G. (1986) The Politics of Irish Freedom (Dingle: Brandon).

Adams, G. (1990) Cage Eleven (Dingle: Brandon).

Adams, G. (1991) Who fears to Speak...? The Story of Belfast and the 1916 Rising (Dublin: AP/RN Print).

Adams, G. (1992) The Street and Other Stories (Dingle: Brandon).

Adams, G. (1994) Selected Writings (Dingle: Brandon).

Adams, G. (1996) Before the Dawn: An Autobiography (London: Heinemann).

Adams, G. (1997) An Irish Voice: The Quest for Peace (Dingle: Mount Eagle).

Adams, G. (2001) An Irish Journal (Dingle: Brandon).

Adams, G. (2003) Hope and History: Making Peace in Ireland (Dingle: Brandon). 
Adams, G. (2005) The New Ireland: A Vision for the Future (Dingle: Brandon).

Adams, G. (2007) An Irish Eye (Dingle: Brandon).

Adams, G. (2016) My Little Book of Tweets (Cork: Mercier).

Adams, G. (2017) Never Give Up: Selected Writings (Cork: Mercier).

Alonso, R. (2007) The IRA and Armed Struggle (Abingdon: Routledge).

Arrington, L. (2016) Revolutionary Lives: Constance and Casimir Markievicz (Princeton, NJ:

Princeton University Press).

Clarke, L. and Johnston, K. (2001) Martin McGuinness: From Guns to Government (Edinburgh: Mainstream).

De Baróid, C. (1989) Ballymurphy and the Irish War (London: Pluto).

Devenport, M. (2000) Flash Frames: Twelve Years reporting Belfast (Belfast: Blackstaff).

English, R. (2003) Armed Struggle: A History of the IRA (London: Macmillan).

Fanning, R. (2015) Eamonn de Valera: A Will to Power (London: Faber and Faber).

Foster, R. (2001) The Irish Story: Telling Tales and Making It Up in Ireland (London:

Penguin Press).

Hopkins, S. (2009) 'Comparing Revolutionary Narratives: Irish Republican self-presentation and considerations for the study of communist life-histories' Socialist History 34, pp. 52-69.

Hopkins, S. (2013) The Politics of Memoir and the Northern Ireland Conflict (Liverpool: Liverpool University Press).

Hopkins, S. (2015) Sinn Féin, the Past and Political Strategy: The Provisional Irish Republican Movement and the Politics of 'Reconciliation', Irish Political Studies 30 (1), pp. 79-97.

Keena, C. (1990) A Biography of Gerry Adams (Cork: Mercier).

McIntyre, A. (2008) And Goodbye Adams? Parliamentary Brief(April). 
Maillot, A. (2005) New Sinn Féin: Irish Republicanism in the twenty-first century (Abingdon: Routledge).

Maynes, M., Pierce, J. and Laslett, B. (2008) Telling Stories: The Use of Personal Narratives in the Social Sciences and History (Ithaca, NY: Cornell University Press).

Moloney, E. (2002) A Secret History of the IRA (London: Penguin).

Moloney, E. (2010) Voices from the Grave: Two Men's War in Ireland (London: Faber and Faber)

Morgan, K. (2005) An Exemplary Communist Life? Harry Pollitt's Serving My Time in Comparative Perspective, in Toye, R and Gottlieb, J. (Eds.), Making Reputations: Power, Persuasion and the Individual in Modern British Politics (London: I.B. Tauris).

Morgan, K., Cohen, G. and Flinn, A. (eds.) (2005) Agents of the Revolution: New Biographical Approaches to the History of International Communism in the Age of Lenin and Stalin (Bern: Peter Lang).

Mulqueen, J. and Smyth, J. (2010) "The Che Guevara of the IRA": the legend of "Big Joe" McCann, History Ireland, 18(1), pp. 46-7.

O’Connor, F. (1991; $1^{\text {st }}$ edn, 1937) The Big Fellow (Dublin: Poolbeg).

O'Doherty, M. (1998) The Trouble with Guns: Republican Strategy and the Provisional IRA (Belfast: Blackstaff Press).

O’Doherty, M. (2007) The Telling Year: Belfast 1972 (Dublin: Gill and Macmillan).

O’Doherty, M. (2017) Gerry Adams: An Unauthorised Life (London: Faber and Faber).

O’Faoláin, S. (1934) Constance Markievicz (London: Jonathan Cape).

Rhodes, R. (2012) Theory, Method and British Political Life History, Political Studies Review, 10(2), pp. 161-76.

Sharrock, D. and Devenport, M. (1997) Man of War, Man of Peace? The Unauthorised Biography of Gerry Adams (London: Macmillan).

Smith, M.L.R. (1995) Fighting for Ireland? The Military Strategy of the Irish Republican Movement (Abingdon: Routledge). 
Tírghrá (2002) Tírghrá - Ireland's Patriot Dead (Dublin: no publisher).

Whalen, L. (2007), Contemporary Irish Republican Prison Writing: Writing and Resistance (Basingstoke: Palgrave Macmillan).

White, R. (2006) Ruairí Ó Brádaigh: The Life and Politics of an Irish Revolutionary (Bloomington, IN: Indiana University Press).

Zwicker, H. (2001-2) Gerry Adams, Moving Target, Canadian Journal of Irish Studies, $27(2) / 28(1)$, pp. $78-95$. 